\title{
Contribution of Recycling of Municipal Solid Waste to the Social Inclusion in Brazil
}

\author{
F. A. M. Lino and K. A. R. Ismail \\ State University of Campinas, Faculty of Mechanical Engineering, Rua Mendeleiev, 200, Cidade Universitária Zeferino Vaz, \\ Barão Geraldo, 13083-860 Campinas, SP, Brazil
}

Correspondence should be addressed to K. A. R. Ismail; kamal@fem.unicamp.br

Received 13 November 2012; Revised 3 February 2013; Accepted 12 February 2013

Academic Editor: Gopal Achari

Copyright (C) 2013 F. A. M. Lino and K. A. R. Ismail. This is an open access article distributed under the Creative Commons Attribution License, which permits unrestricted use, distribution, and reproduction in any medium, provided the original work is properly cited.

\begin{abstract}
This paper proposes the selective collection and recycling as alternative ways to promote the social inclusion in Brazil and help the country to eradicate extreme poverty and misery and achieve the first of the Millennium Development Goals (MDG1) of the UN. This work is based on the data from a Brazilian metropolitan city of Campinas and is extended to Brazil. The results show that the municipality of Campinas collects monthly 8000 tons of recyclables which if recycled can avail jobs to nearly 13,000 waste collectors with a minimum national salary of R \$622/month or alternatively can create 40,280 Family Grants of R $200 /$ month. In Brazil, the collected recyclables potential is about 2.4 million tons per month which can avail jobs to 2,350945 waste collectors or alternatively create about 7.3 millions Family Grants.
\end{abstract}

\section{Introduction}

The combat against extreme poverty and hunger turned to be a challenge for several segments of the society and public authorities. In order to ensure the human rights such as alimentation, health, and education to millions of human beings living in precarious conditions, the United Nations Organization (UN) created the so called "Millennium Development Goals" (MDGs) in 2000 [1]. The MDGs are composed of eight socioeconomic goals, one of which is explicitly related to the present paper, that is, MDG1 which refers to the eradication of extreme poverty and hunger [1]. About 1.4 billions or $20 \%$ of the world population live in conditions of extreme poverty surviving on less than US $\$ 1.25 /$ day, while about 2.7 billions or $40 \%$ of the world population live in the poverty conditions with US\$2/day $[1,2]$. The lack of jobs or even sub jobs is one of the principal factors leading to the impoverishment of the population. In 2007, the amount of poor workers in Latin America reached $59 \%$ of the population and increased to $64 \%$ in 2009 [2,3].

In an attempt to alleviate this critical situation, the UN together with 191 nations took the lead to indicate social measures and targets to be achieved until 2015, to combat the inequalities, and to improve the world human development. Among the actions adopted by governments is the Conditioned Transfer Programs (CTP). In Brazil, for example, the Federal Government implemented the zero hunger program "Fome Zero" which included among several acts the Family Grant program [4].

One activity that can contribute to creating jobs and income is related to the reuse or recycling of solid waste generated in the urban areas. Studies in developing countries show that the collection and recycling of solid waste have been great allies for the social inclusion, as in Colombia [5].

This paper presents the results of a case study based on official data and the impacts of the selective collection and recycling as means for the socioeconomic inclusion and combat against misery and hunger. The results were extended to Brazil, and the overall socioeconomic impacts are evaluated, presented, and discussed.

1.1. Selective Collection in Brazil. According to the data of Pesquisa Nacional de Saneamento Básico (PNSB), the country collects about $259,547 \mathrm{t} /$ day of municipal solid waste (MSW). The solid waste produced per capita in Brazil amounts to $0.74 \mathrm{~kg} /$ day [6]. 
TABLE 1: Composition of the household solid waste from Brazil and Campinas.

\begin{tabular}{lcc}
\hline Waste composition & $\begin{array}{c}\text { Brazil, 1990 } \\
(\%)\end{array}$ & $\begin{array}{c}\text { Campinas, 1996 } \\
(\%)\end{array}$ \\
\hline Organic matter & 52.5 & 46.0 \\
Paper and cardboard & 24.5 & 20.0 \\
Plastics & 2.9 & 15.0 \\
Glass & 1.6 & 2.0 \\
Metal & 2.3 & 4.0 \\
Others & 16.2 & 13.0 \\
\hline
\end{tabular}

Source: PMC [8], IPT/Cempre [9].

TABLE 2: Diagnosis of the solid waste from Campinas.

\begin{tabular}{|c|c|}
\hline Description & Campinas \\
\hline Total collected solid waste (t/month) & $19,650.0$ \\
\hline $\begin{array}{l}\text { Fraction of recyclables contained in the } \\
\text { collected mix }(\%)\end{array}$ & 41.0 \\
\hline $\begin{array}{l}\text { Mass of collected gross recyclables by the } \\
\text { official collection system (t/month) }\end{array}$ & 210.0 \\
\hline Mass of collected rejected material (\%) & 21.7 \\
\hline Mass useful of collected selective ( $\mathrm{t} / \mathrm{month}$ ) & 164.43 \\
\hline $\begin{array}{l}\text { Estimate of financial gain from selling the } \\
\text { recyclables }(\mathrm{R} \$)^{*}\end{array}$ & $98,658.00$ \\
\hline Number of socially included waste collectors & 158 \\
\hline \multicolumn{2}{|l|}{ Recycling potential of solid waste } \\
\hline $\begin{array}{l}\text { Estimated potential of collected recyclables } \\
(\mathrm{t} / \mathrm{month})\end{array}$ & $8,056.5$ \\
\hline $\begin{array}{l}\text { Financial gain due to selling the potentially } \\
\text { available recyclables }(\mathrm{R} \$)^{*}\end{array}$ & $4,833,900$ \\
\hline $\begin{array}{l}\text { Maximum number of socially included } \\
\text { waste collectors** }\end{array}$ & 7,771 \\
\hline $\begin{array}{l}\text { Maximum number of equivalent Family } \\
\text { Grant }^{* * *}\end{array}$ & 24,169 \\
\hline
\end{tabular}

The selective collection was initiated in Brazil in the 1980 decade. Only 994 of the 5,564 Brazilian municipalities have selective collection programs in 2008. According to the IBGE [6], the quantity of solid waste selectively collected in the country is of approximately $3122 \mathrm{t} /$ day which corresponds to $1.2 \%$ of the total mass of the MSW in the country.

1.2. Selective Collection and Recycling in Campinas. Campinas (SP) is classified among the thirteen big cities in Brazil and is the third big municipality of the State of São Paulo having a population of 1,088.611 inhabitants of which $98.6 \%$ are concentrated in the urban area. It is also considered the biggest economic development center in the State of São Paulo. The GDP per capita in Campinas is R 26,133 and the HDI is 0.852 [7].
TABLE 3: Diagnosis of the solid waste from Brazil.

\begin{tabular}{lc}
\hline Description & Brazil \\
\hline Total collected solid waste (t/month) & $7,786,410.0$ \\
$\begin{array}{l}\text { Fraction of recyclables contained in the } \\
\text { collected mix (\%) }\end{array}$ & 31.3 \\
$\begin{array}{l}\text { Rejected material (\%) } \\
\text { Mass of useful collected recyclables (t/month) }\end{array}$ & 21.7 \\
$\begin{array}{l}\text { Financial gains from selling the recyclables } \\
(\mathrm{R} \$)^{*}\end{array}$ & $73,335.8$ \\
Number of socially included waste collectors & $44,001,480$ \\
\hline Recycling potential of solid waste & 70,742 \\
$\quad \begin{array}{l}\text { Estimated potential of collected recyclables } \\
(t / \text { month) }\end{array}$ & $2,437,146.33$ \\
$\quad \begin{array}{l}\text { Financial gains due to selling the potentially } \\
\text { available useful recyclables (R } \$)^{*}\end{array}$ & $1,462,287,800$ \\
$\quad \begin{array}{l}\text { Maximum number of socially included } \\
\text { waste collectors }\end{array}$ & $2,350,945$ \\
$\quad \begin{array}{l}\text { Maximum number of equivalent Family } \\
\text { Grant }\end{array}$ & $7,311,439$ \\
\hline
\end{tabular}

${ }^{*}$ Calculated based on the price of $\mathrm{R} \$ 600.00$.

** Financial value of the Family Grant is $\mathrm{R} \$ 200$.

\section{Method of Analysis}

In this section the sequence of calculations is described. From the official reports of the municipality, real estimates of the gross collected solid waste are determined. After the sorting processes the rejected recyclables are weighted and presented as the rejection index. Knowing the amount of useful recyclables (gross mass, rejected mass) and knowing the price of the recyclable mix per ton one can calculate the financial gain from selling the recyclables. The price of recyclables is obtained from the buyers and cooperative units price lists $[10,11]$.

Knowing the monthly financial gain from selling the recyclables and the salaries practiced at the time (informed by the cooperative units) one can calculate the number of waste collectors that can be employed. Also knowing the value of the Family Grant practiced by the government it is possible to determine the number of additional Family Grants which could be created.

From the IBGE official data [6] the solid waste collected in Brazil was treated in a similar manner to that used in the case of Campinas. The results of the calculations are shown in Tables 2 and 3.

\section{Results and Discussion}

Campinas collected in 2005 around $655 \mathrm{t}$ /day of residential solid waste of which $7 \mathrm{t} /$ day of recyclables were collected selectively $[10,11]$. Table 1 shows the composition of solid waste in Campinas and in Brazil $[8,9]$.

From Table 1 one can observe that the indexes of recyclables in Campinas and Brazil are $41 \%$ and $31.3 \%$, respectively. 
Another important comment can be made in relation to glass, where one can observe that the national index is more than the Campinas index indicating that glass is still widely used as containers for many industrial and commercial products.

3.1. Campinas. The rejection index for the city of Campinas was calculated based on official data and measurements, and it was found to be $21.7 \%$ [10]. This index was applied to the selective collection of Brazil. The gross selective collection of Brazil amounts to $93,660 \mathrm{t} / \mathrm{month}$, and when applying the estimated national rejection index, the rejected matter in the national selective collection is $20,324 \mathrm{t} /$ month.

Table 2 shows the summary of the selective collection data of Campinas and the calculated parameters such as, the amount of recyclables effectively reused, estimate of the potential of generated recyclables, its commercial value, the number of waste collectors posts which could be created in the selective collection activities, the number of waste collectors posts which could be created if the whole potential of recyclables is used, and finally the additional number of Family Grants that could be created.

Generally, during the separation of the solid waste, the recyclables are submitted to some amelioration processes to increase its selling value. Such processes include pressing, bailing, and packing to facilitate handling, storing, and transport. The prices are normally stipulated by the individual buyers or by the interested companies. To calculate the financial funds from selling the recyclables, the authors had to use the prices practiced according to the information supplied by the cooperative units. These prices suffered variations due to the recyclables market financial stability. Average price per ton of recyclables mix in Campinas is estimated as $R \$ 600.00$. This value was used in the present estimates.

One can observe from the results that the estimated financial funds from recycling in Campinas represent $1 / 49$ of its recycling potential or $2 \%$ of the potential of generated recyclables.

The Campinas recycling program involved 190 waste collectors $[10,11]$. In order that each collector receives the monthly income of $\mathrm{R} \$ 622$, it is necessary that the quantity of useful recyclables collected by the municipal government be increased by about $33 \mathrm{t} /$ month totalizing $197 \mathrm{t} /$ month or $1.036 \mathrm{t} / \mathrm{month}$ per waste collector.

If the total potential (selective collection/recycling) is reused, it is possible to permit the inclusion of a larger number of excluded poor families and can be used as an effective instrument for social inclusion, as shown in Table 2.

Calculations were done to estimate the number of Family Grants which can be created by the selective collection and recycling in Campinas, and it was found that the funds could be enough to attend 24,169 poor citizens in Campinas.

The registered incidence of poverty in Campinas, in 2003, according to IBGE [3] data was $13.06 \%$ or about 142,100 poor citizens. In this way, the estimated funds from utilizing all the potential of recyclables in Campinas could benefit about 17\% of the poor population.
3.2. Brazil. According to the data available in 2008 , the selective collection of recyclables from the 3,672745 residences in Brazil reached a quantity of $93,660 \mathrm{t} / \mathrm{month}$. This amount represents $1.2 \%$ of the total solid waste or $11 \%$ of the potential of generation of recyclables in the country as shown in Table 3.

One can show that the monthly total collected recyclables, which represent $3.8 \%$ of the estimated potential for generating recyclables in the country, permit the social inclusion of around 70,741 waste collectors.

\section{Conclusions}

Some conclusions could be made based upon the present study.

(1) Recycling can promote the social inclusion in Brazil since it creates jobs and income. Also it offers other benefits including significant contributions to environmental sustainability.

(2) The results show that in the case of the municipality of Campinas, if all the monthly available potential of recyclables was used the financial funds can avail jobs to nearly 7700 waste collectors, each receiving a minimum national salary of $\mathrm{R} \$ 622 /$ month or alternatively can be used to create 24,169 additional Family Grants at the value of R $\$ 200 /$ month.

(3) In Brazil, the collected recyclables potential is about 2,4 millions tons per month which if reused can create jobs for 2,35 millions waste collectors or alternatively creates 7,3 millions Family Grants.

(4) The program of selective collection and recycling can be considered as an alternative route to achieve the objectives of the first recommendation of the UN (MDG1) and can be inserted in the public policies of less developed countries to improve their human development index.

(5) It is shown that selective collection and recycling can be used to increase the family earnings. Brazil had about 8.9 millions citizens within the extreme poverty limit. Consequently, the estimated financial funds from selling the recyclables generated in the country could benefit about $82 \%$ of the Brazilian population in the conditions of extreme poverty inscribed in the program "Family Grant" of the Federal Government.

(6) The selective collection and recycling can be viewed as a strong vector towards a sustainable ambient by simple and continuous acts directed towards the efficient energy utilization and the conservation of available natural resources. In this manner, the selective collection and recycling can ensure the sustainability of the ambient, reduce the ambient degradation, reduce the emissions to the atmosphere, reduce the contamination of the soil, water, and reduce the thermal and energy impacts. 


\section{Acknowledgments}

The authors wish to thank the CNPQ for the Doctorate scholarship to the first author and the PQ research grant to the second author.

\section{References}

[1] UN, “The Millennium Development Goals Reports," United Nations, New York, NY, USA, 2009, http://www.un.org/.

[2] UN/Cepal, "Statistical Yearbook for Latin America and the Caribean 2009," Santiago de Chile. United Nation, 2010, http:// www.un.org/.

[3] Fundação Instituto Brasileiro de Geografia e Estatística, IBGE, "Síntese de Indicadores Sociais. Uma análise das condições de vida da população brasileira," IBGE, Rio de Janeiro-RJ, 2009, http://www.ibge.gov.br/home/estatistica/populacao/condicaodevida/indicadoresminimos/sinteseindicsociais2009/indic _ sociais2009.pdf.

[4] BRASIL, "Programa Bolsa Família. Relatórios e Estatísticas," Ministério do Desenvolvimento Social e Combate à Fome, 2010, http://www.mds.gov.br/.

[5] M. Medina, "Scavenger cooperatives in Asia and Latin America," Resources, Conservation and Recycling, vol. 31, no. 1, pp. 5169, 2000.

[6] Fundação Instituto de Geografia e Estatística, IBGE, "Pesquisa Nacional de Saneamento Básico 2008," Rio de Janeiro, 2010.

[7] Fundação Instituto Brasileiro de Geografia e Estatística, IBGE, “Cidades. População do município de Campinas," IBGE, 2012, http://www.ibge.gov.br/cidadesat/topwindow.htm?1.

[8] PMC, “Gestão dos Resíduos Sólidos Urbanos," Prefeitura Municipal de Campinas Secretaria de Serviços Públicos. Campinas, Brasil, 1996.

[9] IPT/Cempre, "Lixo municipal: manual de gerenciamento integrado," Instituto de Pesquisa Tecnológica \& Compromisso Empresarial para Reciclagem. São Paulo. SP, 2000.

[10] F. A. M. Lino, "Consumo de energia no transporte da coleta seletiva de resíduo sólido domiciliar no município de Campinas (SP)," FEM/UNICAMP: Campinas, 2009.

[11] F. A. M. Lino, W. A. Bizzo, E. P. da Silva, and K. A. R. Ismail, "Energy impact of waste recyclable in a Brazilian metropolitan," Resources, Conservation and Recycling, vol. 54, no. 11, pp. 916922, 2010. 

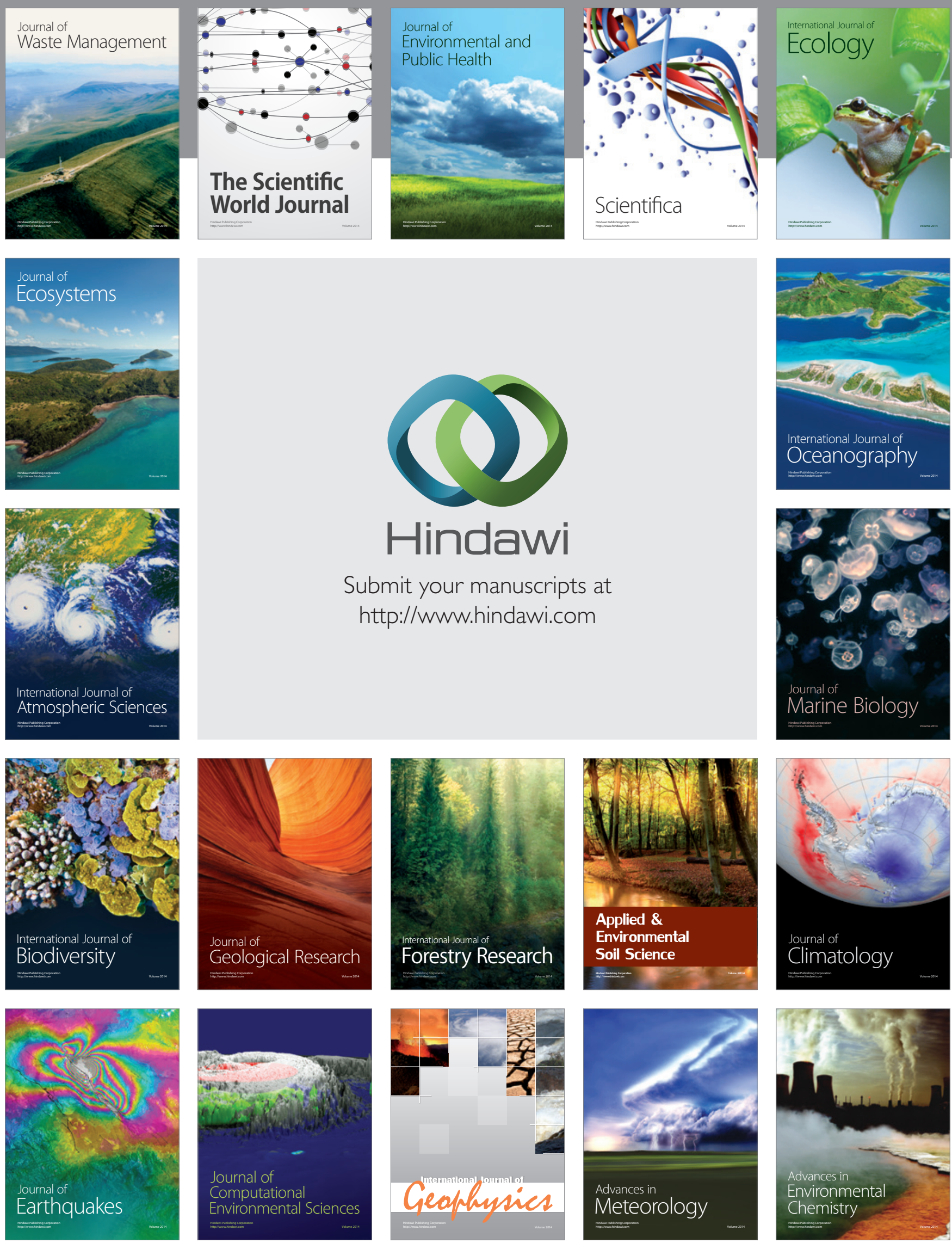